\title{
On The Influence Of Atmospheric Pressure Upon The Burning Of Time-Fuses
}

\section{E. Frankland F.R.S.}

To cite this article: E. Frankland F.R.S. (1861) On The Influence Of Atmospheric Pressure Upon The Burning Of Time-Fuses, Royal United Services Institution. Journal, 5:18, 349-353, DOI: 10.1080/03071846109416756

To link to this article: http://dx.doi.org/10.1080/03071846109416756

曲 Published online: 25 Sep 2009.

Submit your article to this journal $\sqsubset \pi$

Џll Article views: 3

Q View related articles $\square$ 


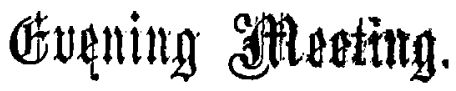

Monday, June 24th, 1861.

CoL. P. J. YORKE, F.R.S., in the Chair.

NAMES of MEMBERS who joined the INSTITUTION between the 17th and 24th June, 1861 .

LIFE.

Browne, Henry, R., Lt.-Col. s7th Royal Irish Fus. 91.

ANNUAL.

Arkwright, A. P., Comr. F N. 1 l. $\quad$ Greville, A, C., Major Unatt. 1 l. I.e Geyt, W _. Esq. Assist. Mil. Storckeeper, Cape of Good Hope.

\section{ON THE INFLUENCE OF ATMOSPHERIC PRESSURE UPON THE BURNING OF TIME-FUSES.}

\author{
By E. Frankrand, F.R.S., \\ Lecturer on Chemistry at St. Bartholomew's Hospital.
}

[Abstracted from a paper read beforo the Royal Society, June 20th, 1861, entitled "On the Influence of Atmospheric Pressure upon some of the Phenomena of Combustion."]

VIrILst engaged in some experiments on the influence of atmospheric pressure upon the rate of combustion of candles, which were found to burn with the same rapidity on the summit of Mont Blauc as in the valley of Chamonix, Colonel Philip Yorke directed my attention to some analogous experiments with the time-fuses of shells, made in India by Quartermaster Mitchell, and which led to a different result. These latter experiments are described in a letter dated Jan. 6, 1855, an extract from which appeared in the Proceedings of the Royal Society.* Quartermaster Mitchell found from a series of carefully conducted experiments, that the rate of combustion of time-fuses was subject to considerable retardation, which heattributed to the diminution of atmospheric pressuro at elevated stations causing a more scanty supply of oxygen. The following is a short statement of the results of these experiments, in which three-inch fuses were burnt under different atmospheric pressures.

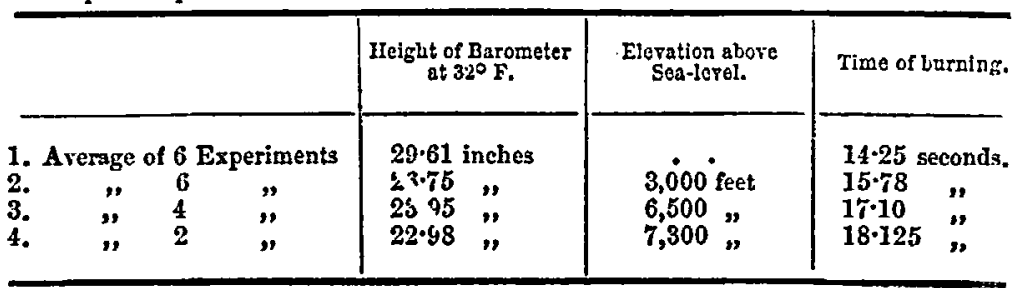

* Proceedings of the Royal Society, vol. vii. p. 316.

YOI, Y,

$2 \mathrm{P}$ 
Comparing the amount of retardation with the corresponding reduction of pressure, we have the following results:-

\begin{tabular}{|c|c|c|}
\hline $\begin{array}{l}\text { Numbers of Experiments between } \\
\text { which comparison is made. }\end{array}$ & Diminution of Pressure. & Retardation of Combustion. \\
\hline $\begin{array}{l}1 \text { and } 2 \\
2 \Rightarrow 8 \\
3 \Rightarrow 4\end{array}$ & $\begin{array}{l}2 \cdot 86 \text { inches } \\
2 \cdot 80 \quad " 1 \\
\cdot 97 \quad "\end{array}$ & $\begin{array}{l}1.53 \text { seconds } \\
1 \cdot 32^{\prime} ", \\
1.025 " ~\end{array}$ \\
\hline
\end{tabular}

Although these results are perfectly compatible with those obtained with candles above alluded to, yet the subject seemed to me of sufficient technical importance to warrant a repetition and extension of these experiments in artificially rarefied air. With this object in view, a large iron cylinder was connected on the one hand with an air-pump, and on the other with a piece of gas-pipe six feet long and four inches internal diameter, the opposite end of the pipe being furnished with an arrangement by which the end of the fuse to be ignited could be introduced air-tight within the pipe, whilst the closed end of the fuse projected about two inches into the external air. The fuses were ignited at a given instant by a voltaic arrangement consisting of ten cells of Grove's battery, an instantaneous contact-maker, and a piece of thin platinum wire which was inserted into the priming of the fuse. In order to ascertain with precision the moment when the deflagration was finished, the lateral hole at the posterior end of the fuse was bored through to the opposite side; a piece of thread was passed vertically through this aperture and secured above to a convenient support, whilst an iron ball was affixed to its lower extremity at a distance of a few inches above a metallic plate upon which the ball fell when the fire rèached the thread, thus indicating the moment when, under ordinary circumstances, the fire of the fuse would be communicated to the contents of the shell. The pressure was indicated by a mercurial gauge inserted into the gas-pipe.

The experiments were made with six-inch fuses (for which I was indebted to the kindness of MIr. Abel, the Director of the laboratory at the Woolwich Royal Arsenal) in the following manner. The fuse being inserted into the end of the gas-pipe, and the necessary degree of exhaustion in the iron cylinder and pipe having been obtained, the fuse was ignited at a given signal. During the continuance of its deflagration an assistant worked the air-pump, so as to prevent any great rise in pressure, whilst another observed the vacuum gauge at the moment when the iron ball dropped. The mean betreen the pressure at the commencement of the deflagration and that at the end, was assumed to be the mean pressure under which the fuse had been burnt; but it is obvious that this assumed mean pressure can only be approximative, although the gauge fell very regularly and gradually during the continuance of the deflagration. 
The following results were obtained:-

\begin{tabular}{|c|c|c|}
\hline \multicolumn{2}{|c|}{$\begin{array}{l}\text { Barometrical Pressure * or } \\
\text { Iteas Pressure. }\end{array}$} & $\begin{array}{l}\text { Time occupted in the Defingration } \\
\text { of each Fise. }\end{array}$ \\
\hline $\begin{array}{r}1 . \\
2 . \\
3 . \\
4 . \\
5 . \\
6 . \\
7 . \\
8 . \\
9 . \\
10 . \\
11 . \\
12 . \\
13 .\end{array}$ & $\begin{array}{l}30 \cdot 4 \text { inches } \\
30 \cdot 4 " \\
30 \cdot 4 " \\
28 \cdot 4 " \\
28 \cdot 1 " \\
25 \cdot 55 " \\
25 \cdot 85 " \\
22.35 " \\
22.55 " \\
19 \cdot 90 " \\
19 \cdot 10 " \\
16.15 " \\
15 \cdot 75 "\end{array}$ & 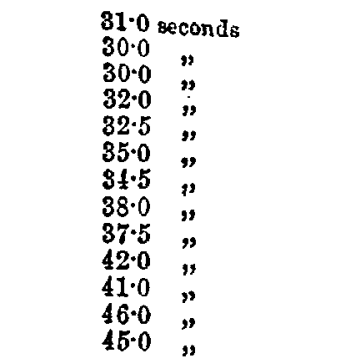 \\
\hline
\end{tabular}

It will be seen from an inspection of the above numbers that, after the three first experiments at atmospheric pressure, an attempt was made to burn two fuses at the same pressure; but, owing to the gauge sinking to the extent of about two inches during the deflagration, the mean pressures at which each pair of fuses was burnt never exactly coincided. For the purpose of comparison, however, it will be convenient to take the mean, both of the pressures and times of burning, of each pair, and to express the results as follows :-

\begin{tabular}{|c|c|c|c|c|}
\hline $\begin{array}{l}\text { Average Pres- } \\
\text { sure in inches of } \\
\text { mercary. }\end{array}$ & $\begin{array}{l}\text { Arerage Time of } \\
\text { Defiagration of } \\
\text { G-inch fuse. }\end{array}$ & $\begin{array}{l}\text { Increase of Time of } \\
\text { burning orer preced. } \\
\text { ing Observation. }\end{array}$ & $\begin{array}{l}\text { 3ieduction of Tressure } \\
\text { correspondipf vrith } \\
\text { increase of time. }\end{array}$ & $\begin{array}{l}\text { Increase of Tinic } \\
\text { for cach diminul- } \\
\text { tion of l-inch } \\
\text { pressture. }\end{array}$ \\
\hline $\begin{array}{l}30 \cdot 40 \\
28 \cdot 25 \\
25 \cdot 70 \\
22 \cdot 45 \\
19 \cdot 65 \\
15 \cdot 95\end{array}$ & $\begin{array}{l}30 \cdot 83 \text { seconds } \\
32 \cdot 25 " \\
34 \cdot 75 " \\
37 \cdot 75 " \\
41 \cdot 50 " \\
45 \cdot 50 ",\end{array}$ & $\begin{array}{l}1.92 \text { seconds } \\
2.50 \quad " \\
3.00 \quad " \\
3.75 \quad " \\
4.00 \quad "\end{array}$ & $\begin{array}{l}2 \cdot 15 \text { inches } \\
2 \cdot 55 " \text { " } \\
3 \cdot 25 ~ " \prime \\
2 \cdot 80 " ~ \\
3 \cdot 50 "\end{array}$ & $\begin{array}{r}.893 \text { scconds } \\
.980 \quad " \\
.925 \quad " \\
1.339 \quad " \\
1.081 \quad "\end{array}$ \\
\hline
\end{tabular}

There are bere evident indications of the rate of retardation being somewhat greater at low than at comparatively high pressures; but, neglecting these indications, the above numbers give 1.043 second, as the average retardation in a six-inch or thirty-seconds fuse for each inch of mercurial pressure removed. This result agrees closely with that obtained by Quartermaster Mitchell, if we except those fuses which he burnt at the greatest altitude, and in reference to which some error must obviously have crept in, either as regards the altitude of the station where the fuses were

- The three first fuses were burnt in the open air, but the arrangements for their ignition, and for determining the cessation of combustion, were the same as in the other leterminations. 
burnt, or the duration of their combustion. The latter source of error is perhaps rendered less improbable from the fact that only two experiments were made at the greatest altitude, whilst six were performed at two, and four at the third of the remaining stations. The following table shows Mr. IItchell's results uniformly with those in the last table. The fuses which he employed being fifteen-seconds or three-inch ones, I have doubled their times of combustion, in order to bring them into comparison with the sixinch fuses which were used in my experiments:-

\begin{tabular}{|c|c|c|c|c|}
\hline $\begin{array}{l}\text { Pressure in } \\
\text { inches of mer- } \\
\text { cury. }\end{array}$ & $\begin{array}{l}\text { Averaze Time of } \\
\text { Combustion of } \\
\text { 6-inch fuse. }\end{array}$ & $\begin{array}{l}\text { Increase of Time of } \\
\text { Combnstion over list } \\
\text { Observation. }\end{array}$ & $\begin{array}{l}\text { Reduction of Pressure } \\
\text { corresponding to } \\
\text { increase of time. }\end{array}$ & $\begin{array}{l}\text { Incrense of Time } \\
\text { for each diminn- } \\
\text { tion of one inch } \\
\text { pressure. }\end{array}$ \\
\hline $\begin{array}{l}29 \cdot 61 \\
26 \cdot 75 \\
23 \cdot 95 \\
22 \cdot 98\end{array}$ & $\begin{array}{l}28.50 \text { seconds } \\
31.56 " \text { " } \\
34.20 ~ " \prime \\
36.25 ~ " 1\end{array}$ & $\begin{array}{l}3.06 \text { scconds } \\
2 \cdot 64 \quad " \quad \\
2.05 \quad " \quad\end{array}$ & $\begin{array}{l}2 \cdot 86 \text { inches } \\
2 \cdot 80 \quad " \\
.97 \quad "\end{array}$ & $\begin{array}{l}1.070 \text { seconds } \\
.943 \quad " \\
2.113 " \Rightarrow\end{array}$ \\
\hline
\end{tabular}

Here, omitting the last determination as abnormal, we have the average retardation in the combustion of a six-inch fuse, for each diminution of oneinch mercurial pressure, equal to $1 \cdot 007$ second, which coincides almost exactly with the number $(1.043)$ deduced from my own experiments.

The results of both series of observations may therefore be embodied in the following law. The increments in time are proportional to the decrements of pressure.

For all practical purposes the following rule may be adopted. Each diminution of one inch of barometrical pressure causes a relardation of one second in a six-inch or thirty-seconds fuse. Or, etch diminution of atmospheric p'essure to the extent of one mercurial inch increases the time of burning by one-thirtieth.

This retardation in the burning of time-fuses by the reduction of atmospheric pressure will probably merit the attention of artillery officers. At present these fuses are carefully prepared so as to burn, at Woolwich, a certain number of seconds; and the perfection with which this is attained is highly remarkable; but such time of combustion at the sea-level is no longer maintained when the fuses are used in more elevated localities. Even the ordinary fluctuations of the barometer in our latitude must render the time of combustion of these fuses liable to in variation of about ten per cent. Thus, a fuse driven to burn 30 seconds when the barometer stands at 31 inches, would burn 33 scconds if the mercurial column fell to 28 inches. The height to which a shell attains in its flight must also exert an appreciable influence upon the burning of its time-fuse: to a still greater extent however must the time of combustion be affected by the position of the fuse during the flight of the shell; if it precede the shell, the time of burning must obviously be considerably shorter than if it follow in the comparatively vacuous space behind the shell.

With regard to the cause of this retardation, it must be borne in mind that the combustille matter of the filse never comes into confact with at- 
mospheric air until it has left the fuse-case; hence the diminished amount of oxjgen in rare atmospheres can have no influence whatever in producing a slower combustion. The composition contains within itself the oxygen necessary for combustion; and a certain degree of heat only is therefore necessary to bring about chemical combination. If this heat were applied simultaneously to every part of the fuse, the whole would burn almost instantaneously. This sometimes approximately occurs, when, by the expansion of the wooden case into which the composition is rammed, a slight space is formed between the latter and the former, thus allowing the deflagration to propagate itself between the case and the composition. Under such circumstances the fuse burns with explosive rapidity, and probably the occasional bursting of shells before, or immediately after leaving tho gun may be due, in some cases, to this cause. Under normal circumstances, however, the fuse burns only at a-disc perpendicular to its axis, and the time occupied in its deflagration necessarily depends upon the rapidity with which each successive layer of composition is heated to the temperature at which chemical combination takes place. This heat necessary to deflagration is evidently derived from the products of the combustion of the immediately preceding layer of composition, and the amount of heat thus communicated to the next unburnt layer must depend in a great measure upon the number of particles of these heated products which come into contact with that layer. Now, as a large proportion of these products is gaseous, it follows, that if the pressure of the surrounding medium be reduced, the number of ignited gaseous particles, in contact, at any one moment, with the still unignited disc of composition, will also be diminished. Hence the slower rate of deflagration in rarefied air. 